\title{
SYNTHESIS: SOME THOUGHTS ON MEDIEVAL CULTURE AND THE TASK OF THE MEDIEVAL PHILOSOPHER
}

The basic drive of the philosophical output of Prof J A L Taljaard can, to my mind, correctly be said to be found in the historiography of philosophy of his Dutch tutor, Prof D H T Vollenhoven. ${ }^{1}$ ) Vollenhoven characterizes post-medieval philosophy as anti-synthetic, in which two options can be taken: either anti-synthetically left or anti-synthetically right. The former rejects a synthesis between pagan philosophy and Christian doctrine (a synthesis which reached its heyday in Medieval Scholasticism), thereby also rejecting the significance of God's Revelation for scientific endeavour. The option to the right also rejects the synthesis between pagan and Christian thought, but is bent upon finding and assigning a proper place to Word Revelation in scientific and cultural endeavour, thereby trying to break down the clerical restrictions forced upon the relevance of Scriptures to all sectors of human life. Against Scholasticism it should be maintained that Scriptures determine not only matters of faith and church life, but is also applicable to other spheres of life. This is exactly what Prof Taljaard wanted and still wants to be: antisynthetically right, a position recently termed by himself as New Right. ${ }^{2}$ )

This basic drive determined his philosophical focus, i e to overcome possible remnants of synthetical thinking in his own philosophical heritage as well as in the philosophical tradition of the Reformation to which he still adheres. Positively it means to work towards an undistorted conception of God, His ordinances for all of creation, and creation itself, and how this "threefold being" (i e God, His ordinances, creation) relate to one another. A fundamental prerequisite for such an undertaking is the light shed by the Scriptures on the field which the (reformationally committed) philosopher investigates. If I am not mistaken, it is precisely this prerequisite for reformational philosophizing, as articulated by Prof Taljaard, that has been hotly debated or fiercely contested. The issues at stake can be formulated in terms of the old Scholastic question: what is the relation of philosophy and theology to each other? 
Whoever poses this question today is in danger of doing so in an already distinctly biased way. This bias consists in identifying philosophy with pagan, albeit secular, thinking in general (stressing the humanness of thinking in a disqualifying manner), and reserving theology for knowledge revealed by Scriptures and passively taken in by man who knows the revealed Truth immediately (thereby underestimating the role of human interpretation and contrasting knowledge and faith in an unjustifiable way). Put briefly, this bias ends up in an inability and unwillingness to recognise the distortion that crept into Scriptural exegesis over the centuries - even during and after the Reformation, and that what is sometimes (rightfully) despised as "philosophy" (meaning thereby pagan or secularistic philosophy) is elsewhere defended as "sound" Christian doctrine.

On the occasion of his sixtieth birthday I have thought it apt to honour Prof Taljaard with some thoughts on one of his (frequently ridden) hobbyhorses in philosophy, i e the problem of a synthesis between paganism and Christianity, and try to tackle the problem (and then rather sideways at that) from the angle of my hobbyhorse in philosophy - philosophy of art. Due to difficulties about the availability of first hand research material on this topic in South Africa, I present these remarks rather hesitantly.

In the Leven van Sinte Christina (Life of St Christine), a hagiography and a Dutchification of an original Latin poem from Contimpré dated 1232, appear the following interesting words:

"daer om so docht mi welgedaen

dat ict latijn in dietsche soud keren

der goeder sinter Kerstinen theren

den genen te troeste die nyet wale

en verstaen latijnsche tale...

Daer om so bid ic Gode den melden

di alle dinghe vermach wel

ende ic anders en heb nyet el

dan roc abijt ende solen ende corde

dat hi geweghen moet so mijn woerde

dat dit gedichte moet troestelec wesen

den ionfrouwen van Mielen alsijt lesen

ende ic hen doch moegh doen daer mede

in eniger manyren troest ende vrede ..."3) 
This fragment not only shows the intention of the poet with a specific poem, but a somewhat generalised conception of poetry can be inferred from it. Bearing this in mind, the genre of this poem becomes especially significant: it is a hagiography, the history of a saint's life, told to edify the reader by holding somebody up as an example who had attained the ideal of beatitude. This individual narrative is taken up in the broader context of the history of salvation, ie whatever happens, happens under the guidance of God who desires the redemption of man. Therefore the specific person whose life story is narrated is not as important as the ideal which is evident from his or her deeds. The saint sets an example which ought to be followed (and imitated). ${ }^{4}$ ) This attitude towards life (whereto poetry must be useful) controls also the more technical aspects of the hagiography in particular (and of the other literary arts in general) $)^{5}$ ): the selection of details which are to be narrated is done in such a way that the lesser edifying is kept silent, or told with trepidation, or narrated with a view to invoke horror or shame or sympathy in the reader. The words (or symbols) used must in some way or another be God-praising and exhorting to the good life.

The latter is especially important. While the poet does not have earthly goods with which he can provide for the ionfrouwen (virgins, i e nuns), he can at least give them words which are troestelec (consoling) and edifying in the life of devotion to onseHeere (our Lord). This requires the poet to choose his words with care, so that he does not distract the attention of the ionfrouwen from the object of devotion (God) and disturb them. Even the words of a poet should direct to God and for those who are not acquainted with Latin, this poet's words must serve as a guidepost for the purified soul on its way to God. Geweghen words - weighed, thoughtfully selected - are given a certain preference: they are the only things on which the soul can rely to attain its hoechste bestemming (highest goal), where to one is prepared by discarding earthly goods and temporal comfort. In the above quoted fragment one has a little speculum or spieghel historiael (mirror of history) of a very special attitude towards life, which - somewhat generalised - is typical of the Christian tradition of the Middle Ages: man on his way to God ${ }^{6}$ ) considering what he sould refrain from doing and what he ought to do, to find his repose and salvation in God. The correctness of 
the relation between man and God is the main focus and the underlying dynamis of this poem and of Christian (literary and fine) art in the Middle Ages. Whatever man does and whatever he leaves undone, he does or leaves undone to find salvation in God.7)

It is very interesting that the idea of the ways of man is so preponderant during the Middle Ages. Add to this the idea of giving prescriptions which serve to guard against any distraction from the way of life to be "in order". The occurence of guideposts on this way as well as knowledge and imitation of them is necessary. The idea of the ways of man gives an important key to the frame of reference of the Medieval mind. These guideposts are either divine directives for the proper conduct on the divinely ordered and structured way, or are things that lead to and signify God. In the latter instances one encounters a widely diffused notion of symbolism: whatever exists, stands for something outside itself, namely God. Behind what appears to man, lies a hidden meaningfulness. ${ }^{8}$ ) The result of this way of looking at the world provides inter alia a cosmology as exegesis of a divine world order, which implies that man is an exegete of creation. What is significant in this view of man's vocation is a certain implied activity in man's dealing with creation which ends up in something esthetic. Man is thought of as revealing the hidden deeper meaning of things and presenting this discovered meaning in vivid imagery - an activity which presupposes insight into the arrangements of cosmic data within the context of symbols, signs and balanced proportions which make up an architectural :.. . ole, i e the factual creation of God, which - as an expression of Him - points to Him.9 ${ }^{9}$ ) Man lives within this specific symbolically structured whole of creation.

A medieval view of human cultural endeavour figures within this broadly (esthetically) formed ontology (resp. cosmology): God is the Prime Artist, man is an imitator of God's work. At best man can only mirror His creation in his works of art. A major prerequisite, therefore, for an overall view on civilization, culture and art during the Middle Ages is clarity about the ontological (resp. cosmological) framework of a medieval theory on civilization, culture and art, which usually includes a concept of order in God's creation, and the specifically designated place and role of man in this creational order. In many respects 
Augustine's concept of order is an important gateway to many later Medieval concepts of culture and man's role in creation. ${ }^{10}$ ) The possibilities (and shortcomings) of neoplatonism since and after Augustine must also be observed as of (some) importance for the development of the later medieval culture and views on culture and the arts. ${ }^{11}$ )

A cursory note on the historical background of the relation between medieval culture and medieval views on culture on the one hand (presented e $g$ in the didascalic literature of these times) and neo-platonism on the other may shed further light on what has been said so far. With the encounter between the claims of the newly spread Christian gospel and the established pagan culture of the Graeco-Roman world the influence of platonism was still felt - in such a way that (I think) it gave in many ways the incentives for the results of such an encounter. (This does not imply that the Christian contribution to this encounter was of minor importance. The point to be stressed here is the fact that many converts to the Christian faith were learned people from the pagan culture, who approached the Christian faith from this pagan background, and tried to come to grips with the conflicting character between paganism and Christianity. They tried to defend the newly won faith by mellowing the conflict character of the encounter and by stressing similarities between paganism and Christianity. The stressing of similarities is sometimes too harshly judged as accommodation or a dilution of the original Christian faith. Such a judgment does not take into account the difficulties in the acceptance of a new world of thought within the framework of an already established, conceptualised, lingually articulated universe of discourse, and adequately expressing the contents of the newly acquired way of thinking in terms of the established conceptual framework without disrupting communication, because the Good Tidings had to be heard by every man!)

This resulted in a spontaneous synthesis of pagan philosophy and Christian doctrine, which found in platonism (and later on: neo-platonism) an ideal framework within which the new Christian body of thought could be designed and worked out. (One should not, I think, neglect the problem of homonyms in this context, i e to understand a pagan meaning when a homonymous word with a 
completely different meaning is used within the original Christian context, thereby obliterating the original Christian import of the concept.) The most prominent characteristic of this prevalent platonism was the relation between the res (Latin) - the ideas in the background - and the adumbration of the ideas in the foreground which make up the universe of the everyday man. In such a set-up the real (the idea) is always hidden from the knowledge of the ordinary man who feasts his eyes on deceptive appearances. To get to the truth one has to work conclusively from the perceptible appearance to the intelligible reality of the idea behind the appearance. In spite of the development of the school of the Sceptics, a kind of cosmology such as platonism offers quite feasible possibilities wherewith the conflict between pagan philosophical views and the contents of the Christian faith can be reconciled: a symbolizing and allegorizing way of dealing with whatever one encounters. That means that whatever one encounters is not taken at face value, but one has to look deeper (or higher) for the real meaning. The actual truth lies on another level than the level of encounter. (The danger of this viewpoint is its strategy: to relegate the conflict to superficiality, and to accommodate rather incompatible views within one system of thought which results in a misinterpretation of the basic tenets of both sides of thought in the conflict.) It is not clearly ascertainable whether platonism did originally suggest the solution to the problems deriving from the conflict between paganism and Christianity during the first few decades of the latter. To pose it by way of a question: was platonism of its own more favourably disposed towards the Christian doctrine whereby its body of thought was more accessible to the Christian faith?

Whatever the case may be, it is nevertheless significant that the first synthesis between themes from the Gospel and strains of pagan thought was brought about by a method of exegesis of pagan thought as well as Scriptures, which altered the contents of both. This method of exegesis consisted of discovering a deeper meaning in a text - which actually meant discovering a kernel of Christian doctrine at the heart of a pagan system of thought, or disclosing the fact that basically the Christian doctrine does not differ so much from a pagan philosophical viewpoint. This reworking of view points underlines the wide significance of exegesis for the cultural endeavour of the early (and later the medieval) Chris- 
tians: it serves as a way of dealing with an alien (and sometimes hostile) cultural heritage. ${ }^{12}$ )

In later times, during the Middle Ages, this method of exegesis was well based on a platonizing line of thought. A way of thinking influenced by neoplatonism since Plotinus almost induced a symbolizing and allegorizing intercourse with nature and the cultural heritage from antiquity. In this respect Hugh of $\mathrm{St}$ Victor serves as a good example. ${ }^{13}$ ) With reference to medieval culture this way of work is of exceptional relevance: it offers a way in which the culture of antiquity (and of the early Christians) can be adapted, accommodated and preserved within an overall Christian institutionally committed conception of life and world. This explains a prominent characteristic of medieval culture, viz a conservational attitude with regard to the past by incorporating the heritage of the past (often by allegorical reinterpretation) in a conception of the way which a faithful Christian had to follow to reach eternal bliss. Apart from the care which was taken of the past, there was also the strong tendency to be mindful of the future, $i$ e to have an unperturbed view of the New Jerusalem. The life of a Christian is therefore characterized by his pilgrimage through this world which does not make this world despicable, but qualifies it in its temporality and transitoriness: everything that a Christian encounters in this world must serve as a salvatory preparation for his eventual blessed life with God. ${ }^{14}$ )

The way of the pilgrim is an ordered way through the creation of God. With this orderly way corresponds a certain tuition system - the artes liberales - which prepares the pilgrim for his final destination. In this way it is of prime importance to be able to follow the way which implies that the pilgrim ought to be equipped to understand the guideposts on his way. The medieval tuition intends to furnish this pilgrim with equipment to deal with signs, symbols and words. ${ }^{15}$ ) $\mathrm{He}$ must be able to interpret, understand and follow or imitate. At the root of medieval culture lies the importance of the word to man - words that had once become incarnate as the Word of God, Christ, the Wisdom of God. So great is the insistence upon the importance of words that Bernard of Clairvaux for instance experienced an existential dilemma between silence and communication. He would rather communicate the stairway of humility to God, that it might serve 
the salvation of others, than keep it to himself ${ }^{16}$ ) - which would have been in accordance with the rules of his monastic order: the observance of silence as demonstration of humility. A striking ambivalence: the prescribed road to salvation can get so narrow that one's own salvation might be imperilled or one's fellow pilgrims might be distracted from the narrow road when silence is observed! Poetic imagery (which stores a crafty dialectic) offers the solution: to break a rule means to go down on the ladder of salvation, to experience humiliation and therefore be raised on the steps of humility nearer to God (which is in Bernard's specific case not the same as rising on the ladder of selfish pride: he broke the rule out of consideration for his fellow-pilgrims and thereby humiliated himself before God.)

The "dilemma" of Bernard of Clairvaux not only draws the attention to the significance of the trans-latio, the handing over of something, i e communication for (medieval) culture, but it also points to another basic characteristic of medieval culture, viz asceticism. We again encounter a certain ambivalence, and it is fashionable for historians to stress the negative side of asceticism in general (and therefore also of medieval asceticism) at the cost of a (possible) positive side. To abstain from certain activities is thought to be more typical of asceticism than the idea of intensive preparatory training. It can not be bluntly maintained that asceticism means cultural anaemia (of which later medieval mystic movements can be accused)

The primary intention of medieval asceticism was to discipline the pilgrim so that he may find his repose in God. The ascetic is driven (by God Himself) by a desire for his God $^{17}$ ) to be reconciled to Him and become fruitful in His service. ${ }^{18}$ ) To this end one must be trained as an athlete trains for his approaching race (in connection with which asceticism was originally practised.) Part of this training was to refrain from certain retarding activities which for the medieval ascetic meant abstention from the fruits and desires of the "world", i e the lure of Evil in this temporal world. Whereas the practice of asceticism amongst early Christians (the desert fathers for instance) seems to hover on the borderline of Good and Evil, and Evil seems temptuously the nearer and even physically the most concrete to the hermit in his seclusion. ${ }^{19}$ ) The practice of the medieval ascetic seems to be more refined 
in its struggle with Evil and in this refinement transforms the problem of Evil to a commendable desire in the life of the ascetic: the need to study Scriptures and contemplate the "mysteries of Christ".

The medieval ascetic does not struggle with Evil physically and bodily (except of course in the hagiographies). His struggle is refined: to coine intellectually to grips with the darkness of ignorance by which Evil imperils the world. The study of Scriptures and the contemplation of the "mysteries of Christ" were intended as soul-lifting, elevating activities, which after some time became articulated in different genres of writing, e $g$ the so-called "literature of silence"20) (of which Bernard of Clairvaux's De Gradibus Humilitatis serves as a fine example), the sermo, the historia, the hagiography, the legend, the miracle, sententiae, florilegiae, etc. ${ }^{21}$ ) Add to this the distance in time which set in between the early Church Fathers' work (with whom asceticism had been an important practice) ${ }^{22}$ ) and the later medieval monks' doings. Small wonder that the way of life and the work of the early Church Fathers was fostered as an attainnable ideal in the medieval monastery. This may account for the definite cultural alignment of the monasteries: a preservation of cultural sources which became in due course the "establishing of a hierarchy, a balance between the sources of culture."'23) The whole cultural set-up which resulted from this is defined by $\mathrm{J}$ le Clerq as follows: ". . Culture includes an overall conception of the world and of life, and the means for expressing it, that is to say, language and the arts. Precisely, language is the foremost of the arts, the art of speaking well, writing well, and of expressing thought well. Thus, language is always the symbol of a culture, and it shows the level of a culture. Therefore, to witness the birth of a homogeneous monastic culture means witnessing the formation of its language as well. Thus we will see the language of the Middle Ages come into being, the one which is to be used by the monastic Middle Ages. It will be, because of its origins, an essentially religious language, that is to say, a language intended to express a religion, and this in the very highest act of religion: worship."24) Although le Clerq infers major characteristics of Medieval culture from an otherwise too generalised view on culture as such, he rightfully stresses the importance of a conception of world and life as a key to culture (in this case Medieval 
culture); and as far as medieval culture is concerned, this means that it is bent upon the proper and fruitful service to God and hostility towards the work of Evil in the world. While this is the case, and that is another important point made by le Clerq, the medieval cultural context is one of taking care of the well-being of man. Cultural endeavour is not hostile to the salvation of man inasmuch as culture is taken to be worship of God. However delineated and narrow the concept of culture may have been during the Middle Ages, this nevertheless is a striking interpretation of (medieval) culture by le Clerq, which means that, if his viewpoint is tenable, the incentive for the development and diversification of culture along Reformational lines is as much determined by a medieval heritage as it is by an early Christian heritage.

The (albeit limited) thoughts on technology in the medieval period deserves our special attention. Where at first the attention of the theorist in the Middle Ages was focussed on the trivium and quadrivium, the medieval mind gradually realised the possibilities of a spectrum of human endeavour. Attempts abounded to find a place for diverse human interests such as ethics, economy and commerce, politics, medicine, agriculture, etc within the design of a united view of culture. The mechanical arts (labour in all its diversifications) were classified under philosophy as one offshoot next to other offshoots such as the theoretical, practical and logical sprouts of the search for Wisdom (philosophy). The work of Hugh of St Victor, along with that of John of Salisbury and Bonaventure, again serve as typical examples. As far as reflection on the fine arts was concerned, the focus on technology resulted in reflection on the technical activity of an artist. Ede Bruijne sketches this development as follows: "Zoals in de 12de eeu w wordt de kunst van de weten schap onderscheiden volgens het beginsel dat de weten schap de oorzaken van de beschouwde waarheid opspoort terwijl de kunst de middelen van een te verwezenlijken resultaat (op grond van de inzicht in die waarheid) voorschrijft. 'Sapientia', zegt Alexander, 'respicit congnitionem ars operationem.' Nochtans onderstelt ook de kunst een soort kennis: de 'poïesis' steunt op een bewustzijn dat het uit te voeren werk concipieert en voorziet, 'ars et prospiciens'. Deze kennis eindig dus niet in zichzelf, als de contemplatie, maar beweegt uiteraard naar de productie van een buiten haar liggend resultaat." ${ }^{25}$ ) The fine arts should not 
be regarded simply as mimêsis (imitation of nature), but rather as "pragmatic": they should function as a useful rule to improve human technique in order to perfect human conduct. Fine arts as imitation of nature became imitation with an explicit designation: the operations of nature were regarded as most perfect and most economic (in the sense of saving unnecessary work). To follow and imitate nature accurately in these aspects human conduct was thought to be instilled with something it lacked, $i$ e the correctness of the workings of nature..$^{26}$ ) The (fine) arts interpreted nature, explained it and taught it to the medieval man. "Ontologisch staat het kunstwerk dus onder de natuurvorm," ${ }^{27}$ ) de Bruijne remarks aptly.

To draw a tentative conclusion from the above-stated (rather incoherent) strains of thought: a debate on the problem of a syn thesis between pagan thought and Christian faith entails more than a definition of thought and faith or - for that matter - a demarkation of philosophy and theology. What is at stake, I think, is a view on the task and method of a philosopher in a cultural conflict situation, viz how he interprets his heritage. To obtain clarity on this problem in medieval times is an assignment for present-day theologians as well, because the interpretation and reinterpretation of (pagan) philosophical concepts crossed the borderline from medieval "philosophy" to "medieval theology". I surmise (on the basis of accessible research material) that not even the sharp distinction between an order of nature and an order of grace prevented or limited the wide application of a method of interpretation, reinterpretation and exegesis which was downright philosophically inspired or at least in its deepest roots philosophically tainted. The matter to be decided then is not to discard philosophy in toto. Philosophical taint as such is no disqualification. What must be decided is whether a specific philosophical taint in one's method of exegesis allows one to understand one's heritage for what it is. Should one submit to (pagan) philosophy for a framework of interpretation (even of Scriptures), or should one submit to Scriptures to find a direction also for the philosophical basis of exegesis?

J J SNYMAN

JOHANNES JURIE SNYMAN, born in Johannesburg in 1947, lectures in Philosophy at the Potchefstroom University for C H E. He is presently engaged in a study of the 
early writings of Georg Lukács. He contributed numerous articles on contemporary, culture and South African politics.

PRESENT ADDRESS: 25 Sita Street, Potchefstroom 2520,

Republic of South Africa. 


\section{NOTES}

1. A complete bibliography of Prof Vollenhoven's work is given in Philosophia Reformata, vol 38 (1973), p 215-228.

2. In a recently completed but yet un published manuscript in which he worked out his own philosophical conception: Polished Lenses.

3. $\quad " .$. Therefore I thought it well to translate the Latin text in Dutch - to the glory of the holy Christina and for the edification of those who do not understand the Latin text so well... Therefore I pray that the merciful and almighty God - because (of my poverty) I possess nothing more than my undergarment, cowl and sandals will direct my words in such a way that this poetical work shall edify the maidens of Mielen whenever they read it, and that I shall give then (with these words) some kind of consolation." For the original, of G S Nienaber \& A P Grové:Christina en Kristien. Kaapstad, Nasionale Boekhandel, nd; $p 62$ et seq.

4. Cf J le Clerq: The love of learning and the desire for God. A study of monastic culture. New York, Fordham University Press, 1961; p 190-206.

5. For Medieval art, cf eg G B Ladner: Ad Imaginem Dei: The image of man in Medieval art in W E Kleinbauer (ed): Modern Perspectives in Western A rt History. New York, Rinehart \& Winston, 1971

6. Cf S U Zuidema: De orde-idee in Augustinus'dialoog De Ordine in Philosophia Reformata, vol 28 (1963), p 1-18. In this study Prof Zuidema contrasts Augustine's view on the theme of homo viator with that of existentialism. For the Christian Augustine it is important that the way of man is an ordered (and in a sense ordained) way, which is not the case with existentialism.

7. An interesting study in this respect is M C Smit: Cultuur en heil. Amsterdam, 1959.

8. Cf M D Chenu: Nature, man and society in the twelfth century. London, University of Chicago Press, 1968; p 99 et seq.

9. This, to my mind, also has implications for Reformational philo sophy. The analysis of H G Geertsema of Dooyeweerd's philosophical conception (Philosophia Reformata, vol 35 (1970), p 23 $56,132-155$ ) tries to show how the problem of meaning and structure, approached with some idea of analogy, determines Dooyeweerd's philosophy.

10. Cf M D Chenu: Op cit, $p 119$ et seq. See also R D Crause: Honorius Augustudonensis: the Arts as via ad patriam in Arts liberaux et philosophie au moyen age. Actes du quatrieme congres international de philosophie medieval. Mon tréal, Institut d'études médievales, 1969; $p 31$ et seq. I hope to return to this subject in a future study, when research material is more easily accessible.

11. M D Chenu: Op cit. p 49 et seq, p 99 et seq. Interesting also is P Courcelle: Die Entdeckung des christlichen Neuplatonismus in C Andresen: Das Augustinusgespräch der Gegenwart, Köln, Wienand-Verlag, 1962; p 125 et seq. Due to difficulties in obtaining literature on Medieval philosophy in South Afirca, I am not prepared to present any views on the role the Aristotelean line of thought played in the encounter and resulting conflict between paganism and Christianity.

12. Cf B J vander Walt: Eisegesis-exegesis, paradox and naturegrace: methods of synthesis in medieval philosophy. Philosophia Reformata vol 38 (1973), p 191 et seq, especially p 192-200.

13. The Didascalicon of Hugh of St Victor; a medieval guide to the arts. Tr from the Latin with an introd and notes by Jerome Taylor. New York, Columbia University Press, 1961. 
14. Cf for example Honorius Augustudonensis: De animae exsilio et patria, discussed by R D Crause: op cit Priscianus, Donatus, Cicero, Aristotle, Boethius, Aratus, Hypocrates all stand ready to teach this pilgrim ad patriam and to raise him to the dignified status of the angels before he arrives at the home of the Divine Wisdom.

15. The importance of the understanding of words is stressed by Hugh of St Victor thus (Didascalicon V, vii): "For the Christian philosopher, reading ought to be a source of encouragement, not a preoccupation, and to feed good desires, not to kill them." See also V. iii: "And the divine Wisdom, which the Father has uttered out of his heart, invisible in itself, is recognized through creatures in them. From this is most surely gathered how profound is the understanding to be sought in the Sacred Writings, in which we come through the word to a concept, through the concept to a thing, through the thing to its idea, and through the idea arrive at the Truth." For sign, see K Kuypers: Der Zeichen- und Wortbegriff im Denken Augustins. Amsterdam, Swets \& Zeitlinger, 1934; p 77-86. The conclusion on p 86 is significant: "Die doctrina christiana beabsichtigt eine Stellungnahme gegenüber der heidnische Kultur zu sein, um das für das christliche Zusammenleben Nützliche zu behalten, und um ihren theoretischen Gehalt, insbesondere aber den logisch-grammatischen und rhetorischen Faktor von falschen Auffassungen gereinigt in der Schriftinterpretation, in der Verkündigung des Wortes und der christlichen Apologetik zu verwenden."

16. Bernard of Clairvaux: De Gradibus Humilitatis. Prefatio. (In the translation of G B Burch: The Steps of humility. Notre Dame (Indiana), University of Notre Dame Press, 1963.)

17. Cf Jean le Clerq: op cit, p 39 et seq; Bernard of Clairveaux: op cit, II, iii-v.

18. Jean le Clerq: op cit, $p 41$

19. Cf the narrations of temptations in Helen Waddell's edition of The desert Fathers. London, Collins, 1962.

20. Jean le Clerq: op cit; $p 188$

21. Ibid, p 187 et seq

22. See for instance B Lohse: Mönchtum und Reformation. Luthers Auseinandersetzung mit dem Mönchsideal des Mittelalters. Gottingen, Vandenhoeck \& Ruprecht, 1963; p 14-105.

23. Jean le Clerq: op cit, $p 156$

24. Ibid, $\mathrm{p} 45$

25. E de Bruijne: Geschiedenis van de Aesthetica. De Middeleeuwen. Antwerpen/Amsterdam. Standaardboekhandel, 1955; p 350-1:"As in the 12th century the arts are distinguished from the sciences by the fact that the sciences discover the causes of the contemplated truth while the arts prescribe the means to realize an intended result (based on an insight in the truth). 'Sapientia', Alexander said, 'respicit cognitionem, ars operationem.' The arts nevertheless presuppose a kind of knowledge: the 'poïesis' relies on a mind which conceives the work to be carried out, 'ars et prospiciens'. This kind of knowledge does not end in itself, as does contemplation, but moves towards the realization of something outside of itself."

26. Ibid, loc cit.

27. Ibid. p 353: " Ontologically the work of art stands under the form of nature." 